Vol. 2, No. 05; 2019

ISSN: 2581-4664

\title{
SATISFACTION RECOVERY MEDIATES THE EFFECT OF INTERACTIONAL JUSTICE ON REPURCHASE INTENTION : STUDY IN BANK MANDIRI BANDA ACEH
}

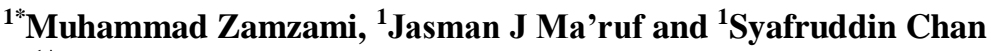 \\ ${ }^{1 *}$ Department of Management, Universitas Syiah Kuala, Indonesia \\ http://doi.org/10.35409/IJBMER.2019.2416
}

\begin{abstract}
The purpose of this study is to examine and analyze the effect of satisfaction recovery and interactional justice toward repurchase intention customers of Bank Mandiri Banda Aceh. The research is conducted at the Bank Mandiri special for Customer located in Banda Aceh. This study uses Non-Probability Sampling, that is the sampling technique that does not give equal opportunity or chance each element or a selected member of the population being sampled. While the sampling technique used is purposive sampling, with number of sample as much as 100 people. The result concludes that interactional justice influences satisfaction recovery significantly, satisfaction recovery influences repurchase intention significantly, Against interactional justice Effect of repurchase intention significantly, interactional justice effects repurchase intention significantly, and interactional justice effects repurchase intention through satisfaction recovery significantly. These findings enrich the knowledge of causality theories and this also as a reference for the practical managers especially for leaders in Bank Mandiri Banda Aceh to pay more attention to the variables related. The originality ies in the verifying of the causality models. This model is an integration from the previous research model, and it is analyzed using SEM. Also, the time and the object can be a new one. The limitation is in the number of variables but can be developed more in the next research.
\end{abstract}

Keyword: satisfaction recovery, interactional justice, repurchase intention.

\section{INTRODUCTION}

Complaint handling qualities over a given bank to the customer is very important to determine the intention of the customer to come back or not. Purchase intention are consequences prominent in the paradigm of satisfaction/dissatisfaction (Oliver, 1996) in Maxham 2002, h.242. Intention is defined as the likelihood that someone will recommend the product or service the company after the failure and recovery efforts, and purchase intent refers to the extent to which the customer intends to buy a product / service in the future. repurchase intention is a repetitive of purchase intention. According to (Kau and Loh, 2006) in (Rashid, Ahmad and Othman, 2014) customer satisfaction as an evaluation of customers after behaving at a certain place and time. (Maxham and Netemeyer, 2002) states that the level of satisfaction has a positive effect on the interest to behave again, in addition to partially mediating justice towards the purchase interest. 


\section{International Journal of Business Management and Economic Review}

Vol. 2, No. 05; 2019

ISSN: 2581-4664

Banks also need to provide a good level of satisfaction on customer complaints. Satisfied consumers are expected to make repeat purchases, thereby creating consumer retention. The better the bank handle on customer complaints, the better the level of customer satisfaction on a complaint, the recovery of customer satisfaction as a benchmark for the customer to a bank. (Smith and Bolton, 1998) in (Maxham and Netemeyer, 2002) defines satisfaction recovery is as customer satisfaction with certain transactions involving the failure and recovery. Then satisfaction recovery means how and results conducted by the company in solving a problem or a complaint addressed to the company.

But in reality, the satisfaction recovery of Bank Mandiri Banda Aceh that is provided has not been able to satisfy customers. Therefore, not a few of the customers who feel disappointed from the shortcomings contained in this bank and make repeated complaints. Customer complaints (customer complaints) is feedback (feed back) from customers who are addressed to companies that tend to be negative. satisfaction recovery is customer satisfaction with certain transactions involving the failure and recovery (Smith and Bolton, 1998) in (Maxham and Netemeyer, 2002). Overall satisfaction of the company refers to the cumulative customer satisfaction with all previous exchange and satisfaction received from the latest exchange. Thus, the company's overall satisfaction is the additive combination of all transactions perception of satisfaction (Oliver, 1996) in (Zaidi, 2016). Customer satisfaction with service recovery means the status of positive emotions felt by customers in the process and the result of the failure to restore services. (Davidow, 2000) in (Kim, Kim and Kim, 2009) define satisfaction with the handling of complaints as a whole affective feelings of customers about the company as a result of complaints the company. The customer complained that he was not satisfied because his expectations were not fulfilled. In this case the customer complains about his dissatisfaction with the interactional justice provided by the independent bank to the customer.

Interactional justice experienced by the customer includes the lack of bank services to the customer, poor communication and no justice that is able to satisfy the services provided bank to customer. Therefore, the higher a customer's expectations of interactional justice, the more likely he is not satisfied with the services he consumes. Customers who are dissatisfied will leave the company and become customers of other companies that can provide better satisfaction with interactional justice. Interactional justice is the extent to which customers feel treated fairly with their personal interactions with service agents during the recovery process. This conceptualization includes elements of politeness, honesty, an interest in justice and the effort felt by complainants and it is consistent with the service recovery literature that still exists ((Smith, Bolton and Wagner, 1999); (Tax, Stephen S; Brown, Stephen; Chandrashekaran, 1998) in (Maxham and Netemeyer, 2002). Evaluation of service recovery is strongly influenced by interactions between customers and service representatives. (Smith, Bolton and Wagner, 1999) found the interactional effect of fairness satisfaction with service recovery meetings, (Tax, Stephen S; Brown, Stephen; Chandrashekaran, 1998) explain the effect of a strong interaction of justice satisfaction with complaint handling

From the reference above, the authors set the research model and hypothesis as follows. 


\section{International Journal of Business Management and Economic Review}

Vol. 2, No. 05; 2019

ISSN: 2581-4664

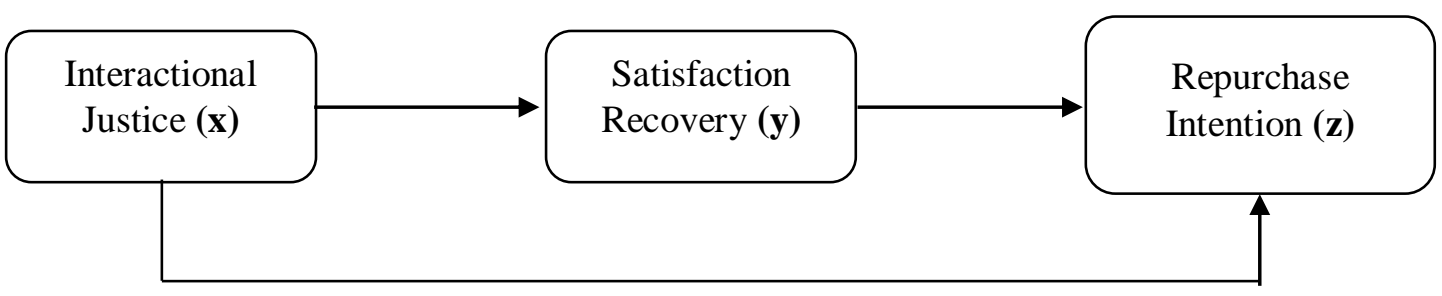

Figure 1. Research paradigm

$\mathrm{H} 1$ : interactional justice effects satisfaction recovery significantly.

$\mathrm{H} 2$ : interactional justice effects repurchase intention significantly

H3: satisfaction recovery effects repurchase intent significantly

$\mathrm{H} 4$ : interactional justice effects repurchase intention through satisfaction recovery significantly

\section{METHOD}

To get the data and information that is accurate and relevant, the authors conduct a study on the Customer Bank Mandiri Banda Aceh. Because the number of customers who have used the bank is unknown for certain, in this study the use of Non-Probability Sampling is required. The sampling technique does not provide opportunities or equal opportunity each element or a selected member of the population being sampled. While the sampling technique used is purposive sampling. (Ferdinand, 2002) says that a good sample size is $100-200$. Given the number of unknown population, sample is determined as much as 100 respondents.

This is the verification research that test the causality of variabkProcessing data obtained is conducted by using a structural equation model (SEM). SEM is a statistic multivariate techniques that able to analyze not only the influence of variables, but also the relationship with the indicator variables respectively. Ha acceptance criteria is Critical Ratio (CR)> 1.96 and the Probability $(\mathrm{P})<0.05$.

Authors also determine the dimensions to measure each variable in this study, that are : 1) interactional justice : Communication / Explanation, Honesty, Politeness, Efforts, and Empathy, 2) satisfaction recovery : Feelings of pleasure over the results obtained, suitability of expectations and result, and Overall satisfaction ; 3) repurchase intention : 1. Transactional interest; 2. Reference interest; 3. Preferential interest; 4. Explorative Interest

\section{RESULT}




\section{International Journal of Business Management and Economic Review}

Vol. 2, No. 05; 2019

ISSN: 2581-4664

The validity test result can be seen from the number of loading factor in the figure 2 below.

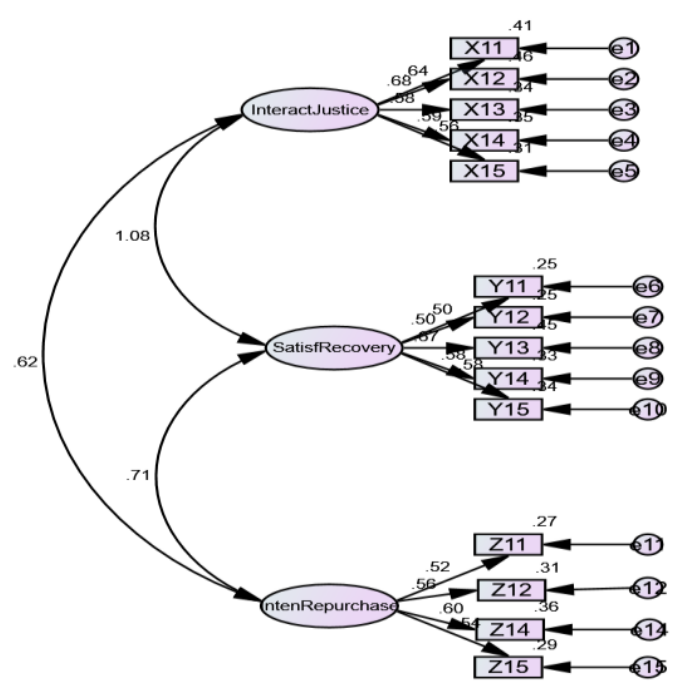

Figure 2. Measurement Model

The figure 2 shows that one indicator of the repurcahse intention variable has been removed because the value is below the loading factor 0.5 . The following table is a net measurement test result that can later be included in the structural testing.

Table 1. Loading Factor

\begin{tabular}{|l|l|l|l|l|}
\hline No. & Indicator & & variables & estimate \\
\hline 1 & X11 & $<---$ & InteractJustice & .643 \\
\hline 2 & X12 & $<---$ & InteractJustice & .677 \\
\hline 3 & X13 & $<---$ & InteractJustice & .582 \\
\hline 4 & X14 & $<---$ & InteractJustice & .588 \\
\hline 5 & X15 & $<---$ & InteractJustice & .559 \\
\hline 6 & Y11 & $<---$ & SatisfRecovery & .502 \\
\hline 7 & Y12 & $<---$ & SatisfRecovery & .501 \\
\hline 8 & Y13 & $<---$ & SatisfRecovery & .671 \\
\hline 9 & Y14 & $<---$ & SatisfRecovery & .576 \\
\hline 10 & Y15 & $<---$ & SatisfRecovery & .584 \\
\hline 11 & Z11 & $<---$ & IntenRepurchase & .515 \\
\hline 12 & Z12 & $<---$ & IntenRepurchase & .559 \\
\hline 13 & Z14 & $<---$ & IntenRepurchase & .601 \\
\hline 14 & Z15 & $<---$ & IntenRepurchase & 537 \\
\hline
\end{tabular}


International Journal of Business Management and Economic Review

Vol. 2, No. 05; 2019

ISSN: 2581-4664

Table 1 shows the loading factor of all existing indicator in the model, and already qualify for further treatment because it has a loading factor $>0.5$.

Table 2. Goodness of Fit

\begin{tabular}{|l|l|l|l|}
\hline Criteria Index Size & Cut-off Value & Results Analysis & Evaluation Model \\
\hline Chi Square & expected to be small & 138088 & Fit \\
\hline CMIN / DF & CMIN / DF $<2$ & 1,817 & Fit \\
\hline GFI & $\geq 0.90$ & 0884 & Fit \\
\hline AGFI & $\geq 0.90$ & 0840 & Well \\
\hline CFI & $\geq 0.90$ & 0.884 & Well \\
\hline PNFI & $0-1$ & PNFI 0-1 & Fit \\
\hline RMSEA & $<0.08$ & 0074 & Fit \\
\hline
\end{tabular}

Furthermore, structural test result provides the information needed to answer the hypotheses that have been built before whether proven or not. The following figure illustrates the influence between variables:

Figure 3. Structural Equation Model

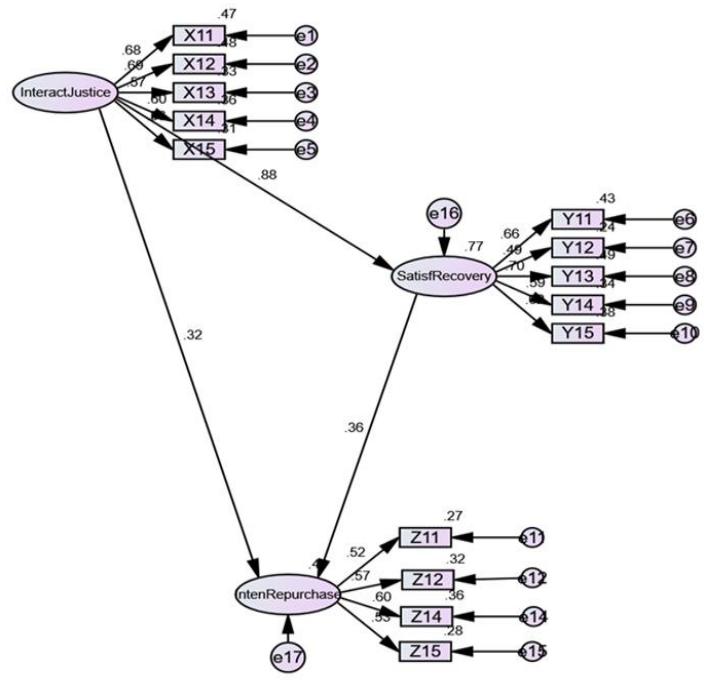

Figure 3 shows the Stuctural research model with the results that answer the hypothesis test, that can be seen clearly in the following table. 
Vol. 2, No. 05; 2019

ISSN: 2581-4664

\section{Table 3. Direct Effect Result}

\begin{tabular}{|l|l|l|l|l|}
\hline No & hypothesis & $\begin{array}{l}\text { CR Cut off }> \\
\mathbf{1 . 9 6}\end{array}$ & $\begin{array}{l}\text { P Value } \\
\text { Cut off }<\mathbf{0 . 0 5}\end{array}$ & $\begin{array}{l}\text { Informatio } \\
\mathbf{n}\end{array}$ \\
\hline 1 & $\begin{array}{l}\text { Interactional Justice influences } \\
\text { satisfaction recovery significantly }\end{array}$ & 6.234 & $* * *$ & $\begin{array}{l}\text { H1 } \\
\text { Accepted }\end{array}$ \\
\hline 2 & $\begin{array}{l}\text { Satisfaction recovery influences } \\
\text { repurchase intention significantly }\end{array}$ & 4.528 & $* * *$ & $\begin{array}{l}\text { H2 } \\
\text { Accepted }\end{array}$ \\
\hline 3 & $\begin{array}{l}\text { Interactional justice effects repurchase } \\
\text { intention significantly }\end{array}$ & 4.525 & $* * *$ & $\begin{array}{l}\text { H3 } \\
\text { Accepted }\end{array}$ \\
\hline
\end{tabular}

From the structural test result directly visible all the hypotheses of hypothesis 1 to hypothesis 3 is accepted. Means there is a significant influence between the independent variable and dependent on each of these hypotheses. From the findings of this direct effects, it describes that interactional justice variable has the greatest magnitude in encouraging the recovery of repurchase intention than satisfaction. In the variable interactional justice the indicator that is lowest perceived by respondents is "Bank officers pay special attention to my problem". Also, in satisfaction recovery the indicator that has a lowest score is "the response of the Bank to the failure of the service better than expected". repurchase intention on indicator that has the lowest value is "I intend to refer to others to use the products of the Bank".

Beside, hypothesis test for indirect effect uses Boostrapping Method that can be described as follows.

Table 4. Indirect Effect Result

\begin{tabular}{|l|l|l|l|}
\hline & InteractJustice & SatisfRecovery & IntenRepurchase \\
\hline SatisfRecovery & $\ldots$ & $\ldots$ & $\ldots$ \\
\hline IntenRepurchase & .002 & $\ldots$ & $\ldots$ \\
\hline
\end{tabular}

It is seen that bootstrapping $\mathrm{p}$ value $=0.002<0.05$ then it is proved that the indirect effect of the interactional justice on repurchase intention through the satisfaction recovery is significant. Because both direct and indirect are significant, then the role of the variable satisfaction recovery here is as a partial mediation. This indicates the satisfaction recovery can be used as a mediation to increase the repurchase intention of customers of Bank Mandiri Banda Aceh. The interactional Justice is also an obligatory of the managers of Bank Mandiri Banda Ache to push it to achieve high performance. This implies that the research model in this study is fit for a model in management, and all variables is relevant with the case of Bank Mandiri Banda Aceh.

\section{CONCLUSION}

The result concludes that interactional justice influences satisfaction recovery significantly, satisfaction recovery influences repurchase intention significantly, Against interactional justice Effect of repurchase intention significantly, interactional justice effects 


\section{International Journal of Business Management and Economic Review}

Vol. 2, No. 05; 2019

ISSN: 2581-4664

repurchase intention significantly, and interactional justice effects repurchase intention through satisfaction recovery significantly. These all causality findings enrich the realm of science and the model can be developed more for the further research. This also can be as a reference for the practical managers especially for leaders in Bank Mandiri Banda Aceh to pay more attention to the variables related. The originality of this study lies in the verifying of the causality models. This model is an integration from the previous research model, and it is analyzed using SEM. Also, the time and the object can be the new one. The limitation is in the number of variables but can be developed more in the next research.

\section{REFERENCES}

Davidow, M. (2000) 'The Bottom Line Impact Of Organizational Responses To Customer Complaints', Journal of Hospitality \& Tourism Research, 24(4), pp. 473-490.

Ferdinand, A. (2002) 'Structural equation modeling dalam penelitian manajemen', Semarang: Badan Penerbit Universitas Diponegoro.

Kau, A. K. and Loh, E. W. Y. (2006) 'The effects of service recovery on consumer satisfaction: A comparison between complainants and non-complainants', Journal of Services Marketing, 20(2), pp. 101-111. doi: 10.1108/08876040610657039.

Kim, T. (Terry), Kim, W. G. and Kim, H. B. (2009) 'The effects of perceived justice on recovery satisfaction, trust, word-of-mouth, and revisit intention in upscale hotels', Tourism Management. Elsevier Ltd, 30(1), pp. 51-62. doi: 10.1016/j.tourman.2008.04.003.

Maxham, J. G. and Netemeyer, R. G. (2002) 'A longitudinal study of complaining customers' evaluations of multiple service failures and recovery efforts', Journal of Marketing, 66(4), pp. 57-71. doi: 10.1509/jmkg.66.4.57.18512.

Oliver, R. L. (1996) Satisfaction: A Behavioral Perspective on the Consumer. New York: Mc Graw Hill.

Rashid, M. H. A., Ahmad, F. S. and Othman, A. K. (2014) 'Does Service Recovery Affect Customer Satisfaction? A Study on Co-Created Retail Industry', Procedia - Social and Behavioral Sciences. Elsevier B.V., 130(May), pp. 455-460. doi: 10.1016/j.sbspro.2014.04.053.

Smith, A. K. and Bolton, R. N. (1998) 'an Experimental Investigation of Customer Reactions To Service', Journal of Service Research, 1(1), pp. 65-81.

Smith, A. K., Bolton, R. N. and Wagner, J. (1999) 'A model of customer satisfaction with service encounters involving failure and recovery', Journal of Marketing Research, 36(3), pp. 356-372. doi: 10.2307/3152082.

Tax, Stephen S; Brown, Stephen; Chandrashekaran, M. (1998) 'Customer Evaluations of for Service Complaint Experiences: Implications Relationship Marketing', Journal of Marketing, 62(2), pp. 60-76.

Zaidi, S. D. A. (2016) How To Overcome Customer Dissatisfaction. the Iqra University. 